\title{
Culture of prostate epithelial cells of the rhesus monkey on extracellular matrix substrate: influence of steroids and insulin-like growth factors
}

\author{
T S Udayakumar ${ }^{1}$, D A Jeyaraj, M Rajalakshmi and R S Sharma \\ Department of Reproductive Biology, All India Institute of Medical Sciences, New Delhi-110029, India \\ ${ }^{1}$ Department of Radiation Oncology, Arizona Cancer Center, 1515 North Cambell Avenue, Tucson, Arizona 85724-5024, USA \\ (Requests for offprints should be addressed to M Rajalakshmi)
}

\begin{abstract}
Rhesus monkey prostate epithelial cells from the cranial lobe were isolated and cultured in flasks coated either with collagen IV or laminin. The effects of stromal cell medium, androgens and growth factors on cell number, thymidine incorporation and secretory activity were assessed.

The results indicate that dihydrotestosterone (DHT) and androstenedione have stimulatory influences on cell proliferation and secretion in coated flasks. DHT was more effective in increasing cell number but the induction of secretory activity was similar with both steroids. The combination of IGF-I and -II resulted in inducing better cell proliferation and secretory activity than the individual IGFs but, of the two IGFs, IGF-I was more effective than
\end{abstract}

IGF-II. DHT with IGFs was more potent in inducing proliferation, differentiation and secretion than androstenedione. Even in the absence of steroids or growth factors, colony formation and confluence occurred in coated flasks but cell differentiation and secretion only to a limited extent.

In conclusion, we were able to establish an in vitro primary culture of prostate epithelial cells from rhesus monkey using extracellular matrix proteins, steroids and growth factors as additional supplements. This culture system may be useful to study prostate cell physiology and to identify drugs that can inhibit cell proliferation.

Journal of Endocrinology (1999) 162, 443-450

\section{Introduction}

Mammalian prostate is a major accessory organ whose structure and functional activities are under the control of androgens (Cunha et al. 1987). In addition to androgens, paracrine substances like growth factors are known to influence prostate physiology. Benign prostatic hyperplasia and prostate cancer are age-dependent disorders of the prostate (Kozlowski et al. 1991). The age-adjusted incidence rate of prostate cancer is higher in the USA compared with other countries. The treatment of these conditions is complicated by the poor response elicited by androgen ablation, since some of the prostate cells lose their androgen dependency when they undergo multiplication (Chiarodo 1991). So, the development of an in vitro culture of prostate epithelial cells in a non-human primate model would help in understanding the role of various factors like androgen, growth factors and matrix proteins in influencing prostate cell proliferation and differentiation.

The present study was therefore undertaken to establish an in vitro culture of monkey prostate cell and to assess the effect of major androgenic steroids, growth factors and extracellular matrix (ECM) elements on the multiplication of cells, their differentiation and induction of secretory activity. Dihydrostestosterone (DHT) was chosen as the androgen of choice since circulating testosterone is $5 \alpha-$ reduced to DHT by the prostate epithelial cells and DHT acts as an intracellular androgen of action (Wilson 1980). Among the paracrine factors, insulin-like growth factors (IGFs) act as mitogens which bind with high affinity and specificity to IGF-binding proteins and influence prostate epithelial cell growth and development (Daughaday 1990). In addition to these, prostate function is also known to be influenced by interaction between stromal cells and epithelial cells of the prostate.

The results of this study indicate that ECM proteins, steroids and growth factors as well as stromal cell secretory products are required for attachment and differentiation of the prostate cells in culture and induction of secretory activity.

\section{Materials and Methods}

\section{Animals}

Four adult male rhesus monkeys (Macaca mulatta; weight $8-10 \mathrm{~kg}$ ) procured from the wild in northern India were quarantined for 3 months in the Primate Research Facility 
of the Institute, underwent routine quarantine procedures described elsewhere (Sivashanmugam \& Rajalakshmi 1997) and were then moved to the main facility for acclimatization. The animals were killed under ketamine anaesthesia $(10 \mathrm{mg} / \mathrm{kg}$ body weight; Themis Chemicals Ltd, Hyderabad, India), the cranial lobe of the prostate was removed under aseptic conditions and processed for culture.

The protocol of the experiment was approved by the Institutional Ethics Committee on the use of non-human primates in biomedical research.

\section{Chemicals}

Collagen IV (Engelbreth Holm Swarm sarcoma), laminin, collagenase, basic fibroblast growth factor, Ham's F-12/ Dulbecco's modified Eagles' medium (DMEM), DNase, foetal calf serum (FCS), insulin, transferrin, selenium, albumin, RPMI-1640, epidermal growth factor (EGF), IGF-I and -II, cholera toxin, hydrocortisone, sodium pyruvate, DHT, androstenedione, cytokeratin and vimentin were purchased from Sigma, St Louis, MO, USA; absolute ethanol was purchased from E Merck, Darmstadt, Germany. The culture flasks and wells were purchased from Nunc (DK 4000, Roskilde, Denmark) and the remaining chemicals from local sources.

\section{Isolation of epithelial and stromal cells}

The culture of prostate epithelial and stromal cells was carried out according to the procedure of Kozlowski et al. (1991). The cranial lobe was washed three times with saline containing gentamycin, minced into small pieces and placed in a sterile Petri dish. The minced tissues were incubated with $0.05 \%$ collagenase containing $2 \%$ FCS and kept at $37^{\circ} \mathrm{C}$ on a rotational shaker for $30 \mathrm{~min}$, which yielded sufficient tissue dissociation. Tissue dissociates were washed and exposed to $0 \cdot 01 \%$ DNase for $10 \mathrm{~min}$. The suspension contained mainly stromal cells. The residue containing the epithelial cell-enriched fraction was layered over 10\% FCS and kept for 30 min for unit gravity sedimentation. While the pellet mainly contained epithelial cells, stromal cells were present in the supernatant. This step was repeated twice. The epithelial cells obtained by this procedure were centrifuged and suspended in $1 \mathrm{ml}$ Ham's F-12/DMEM medium containing 10\% FCS. The cell viability was $90 \pm 5 \% \quad(n=10)$ determined by the trypan blue $(0 \cdot 4 \%)$ exclusion method.

\section{Preparation of stromal cell medium (SCM)}

Isolated stromal cells were grown to subconfluence in RPMI-1640 medium supplemented with 10\% heatinactivated FCS, penicillin $(10000 \mathrm{U} / \mathrm{l})$, streptomycin $(100 \mathrm{mg} / \mathrm{l})$ and gentamycin $(50 \mathrm{mg} / \mathrm{l})$. The culture flasks were washed three times with phosphate-buffered saline
(PBS; 0.1 M) and fresh RPMI-1640 medium containing insulin, transferrin, selenium ( $5 \mu \mathrm{g} / \mathrm{ml}$ each) and albumin $(1 \mathrm{mg} / \mathrm{ml})$ were added and incubated at $37{ }^{\circ} \mathrm{C}$ in a humidified incubator in an atmosphere of $95 \%$ air: $5 \%$ $\mathrm{CO}_{2}$. After 3 days, the SCM was harvested, lyophilized and stored at $-70{ }^{\circ} \mathrm{C}$.

\section{Preparation of collagen $I V$ - and laminin-coated flasks}

Collagen IV was prepared by reconstitution of the original vial in $0.25 \%$ acetic acid to give a concentration of $1 \mathrm{mg} / \mathrm{ml}$ and aliquots were stored at $-20{ }^{\circ} \mathrm{C}$. The working dilution was prepared by diluting the stock solution of collagen IV to $10 \mu \mathrm{g} / \mathrm{ml}$ with sterile distilled water. One millilitre of this solution was added to culture flasks and allowed to dry in air at room temperature. Dried coated flasks were sterilized by overnight exposure to uv light in a sterile hood. All collagen-coated flasks were preincubated for $1 \mathrm{~h}$ at $37^{\circ} \mathrm{C}$ with $1 \mathrm{ml}$ Ham's F-12/DMEM containing 10\% FCS.

Laminin $(1 \mathrm{mg} / \mathrm{ml})$ was thawed and reconstituted with sterile media to give a concentration of $30 \mu \mathrm{g} / \mathrm{ml}$ and stored as aliquots at $-20{ }^{\circ} \mathrm{C}$. The culture flasks were coated as given above.

\section{Culture of prostate epithelial cells}

Isolated epithelial cells were plated $\left(2 \times 10^{6} /\right.$ flask $)$ in coated flasks $\left(25 \mathrm{~cm}^{2}\right)$. Ham's F-12/DMEM containing FCS (10\%), horse serum (5\%), penicillin (10 $000 \mathrm{U} / \mathrm{l})$, streptomycin $(100 \mathrm{mg} / \mathrm{l})$ and gentamycin $(50 \mathrm{mg} / \mathrm{l})$ were added to each flask, which were left undisturbed at $37{ }^{\circ} \mathrm{C}$ in an atmosphere of $95 \%$ air:5\% $\mathrm{CO}_{2}$. After $36 \mathrm{~h}$ the medium was replaced by medium containing horse serum $(10 \%)$, FCS $(5 \%)$, insulin $(5 \mu \mathrm{g} / \mathrm{ml})$, transferrin $(5 \mu \mathrm{g} / \mathrm{ml})$, selenium $(5 \mu \mathrm{g} / \mathrm{ml})$, EGF $(10 \mathrm{ng} / \mathrm{ml})$, pituitary extract $(25 \mu \mathrm{g} / \mathrm{ml})$, cholera toxin $(100 \mathrm{pg} / \mathrm{ml})$, sodium pyruvate $(110 \mu \mathrm{g} / \mathrm{ml})$ and hydrocortisone $(5 \mu \mathrm{g} / \mathrm{ml})$ and cultured for 18 days with replacement of the medium twice a week.

\section{Role of steroids on epithelial cell culture}

To study the effects of DHT or androstenedione on cells in culture, the steroids were dissolved in absolute ethanol (E Merck) and diluted to appropriate concentration $(5,10$, $20 \mathrm{nM}$ ) in F-12 medium. After the first $36 \mathrm{~h}$ of the attachment period, $100 \mu \mathrm{l}$ of these steroids were added to the culture wells containing enriched medium and mixed gently.

The effects of SCM on cells in culture were simultaneously evaluated by exposing the cells in culture to $20 \%$ SCM. The cultures were maintained for 14, 16 and 18 days. The number of cells that attached was determined by detaching the cells using cold medium, staining with trypan blue followed by counting the cells in a haemocytometer. 
Role of IGF-I and IGF-II on epithelial cell culture

To analyze the effects of IGF-I, IGF-II or a combination of the two growth factors, they were added to the culture flasks after $36 \mathrm{~h}$ of attachment at concentrations of $10 \mathrm{ng} / \mathrm{ml}$ since pilot experiments showed that this concentration of IGF gave optimal results (authors' unpublished observations). IGF-I and IGF-II were dissolved in $10 \mathrm{mM} \mathrm{HCl}$ or $10 \mathrm{mM}$ acetic acid respectively. Aliquots of these were resuspended in F-12 medium to give a concentration of $1000 \mathrm{ng} / \mathrm{ml}$. Ten microlitres of this were added to the flasks containing enriched medium.

\section{Immunostaining}

After 18 days of culture, the epithelial cells were fixed with 3\% formaldehyde in PBS for $15 \mathrm{~min}$ at $25^{\circ} \mathrm{C}$. Fixation was terminated by incubating the cells in cold PBS containing $0 \cdot 2 \mathrm{M}$ glycine for $10-15 \mathrm{~min}$. The cells were rinsed with PBS and exposed to $1 \%$ bovine serum albumin for $1 \mathrm{~h}$ at room temperature. The blocking solution was removed and a uniform layer of primary antibody (monoclonal anti-pan cytokeratin antibody, 1:400) was added and incubated for $2 \mathrm{~h}$. The excess antibody was removed, and cells were washed twice with PBS and incubated with second antibody (goat anti-rabbit IgG tagged with fluorescein isothyiocyanate, 1:100) for $1 \mathrm{~h}$. After washing twice with PBS the cells were mounted and observed under an epifluorescence illumination (Nikon, Japan) using Ploemopak 12 filter block (excitation filter BP 450-490 and suppression filter LP 515). The images were recorded on Kodak gold 100.ISO films.

\section{Histology}

The epithelial cells, grown in culture as mentioned above, were observed under inverted phase contrast microscope (Nikon, Japan) and the images were recorded on Nova 125 ASA films.

\section{[3] Thymidine incorporation}

$\left[{ }^{3} \mathrm{H}\right]$ Thymidine incorporation was carried out according to the method of MacDonald et al. (1990). Epithelial cells were grown to subconfluence, counted and plated at a density of $1 \times 10^{4}$ cells/well in 96-well plates (Nunc) in Ham's F-12/DMEM containing 0.5\% FCS. After 36 h the cells were washed and the medium was replaced with supplements, steroids and growth factors. Control wells contained medium with supplements only. The cells were cultured for 14, 16 and 18 days in the presence of 95\% air:5\% $\mathrm{CO}_{2} \cdot\left[{ }^{3} \mathrm{H}\right]$ Thymidine $(10 \mu \mathrm{Ci} /$ well, specific activity $75 \mathrm{GBq} / \mathrm{mmol}$; Dupont NEN Research Products, Boston, MA, USA) was added to the cells $12 \mathrm{~h}$ before the termination of culture. After incubation, the medium was aspirated and fresh medium $(200 \mu \mathrm{l})$ was added to the wells. Ice-cold 10\% trichloroacetic acid (50 $\mu \mathrm{l})$ was added to the wells. After $2 \mathrm{~h}$, the cells in the wells were harvested on filter mats (GF filter). Wells were washed three times with distilled water and aspirated through cell harvester (PHD cell harvester; Cambridge Technology, Inc., Watertown, MA, USA). The filter mats were dried at $60{ }^{\circ} \mathrm{C}$ for $30 \mathrm{~min}$, scintillation fluid containing $12.5 \mathrm{~g}$ PPO (2,5 diphenyloxazole) and $1 \cdot 25 \mathrm{~g}$ dimethyl POPOP $(1,4$ bis[4-methyl 5-phenyl-2-oxazolyl] benzene) in $2 \cdot 5$ litres toluene was added and counted in a liquid scintillation spectrometer (Wallac 1410 Liquid Scintillation Counter; Pharmacia, Piscataway, NY, USA).

\section{Determination of prostate specific antigen (PSA) levels}

The levels of PSA were measured in the culture medium by the solid phase sandwich immunoradiometric assay using the kits supplied by Immunocorp Sciences Inc., Montreal, Quebec, Canada. The assay used polyclonal antihuman PSA antibodies immobilized on plastic tubes as capture reagent and two iodinated monoclonal antibodies as tracer. The polyclonal antibody-coated plastic tubes (solid phase) were exposed to culture medium for $90 \mathrm{~min}$ at room temperature with horizontal rotation set at 120 r.p.m. The tubes were decanted, drained and $250 \mu \mathrm{l}$ monoclonal anti-PSA antibody cocktail labelled with ${ }^{125} \mathrm{I}$ in a protein matrix was added. The tubes were incubated for $90 \mathrm{~min}$ at room temperature using a horizontal rotator at 120 r.p.m., decanted and drained. The radioactivity was measured in a gamma counter (Wallac 1470 Wizard, automatic gamma counter; Pharmacia). The amount of PSA in the culture medium was calculated by logit-log transformation of the counts obtained. The assay has a sensitivity limit of $0.03 \mathrm{ng} / \mathrm{ml}$ and had no cross-reaction with other proteins and polypeptides ( $\alpha$-feto-protein, carcinoembryonic antigen, human chorionic gonadotrophin, lactalbumin and prostatic acid phosphatase). The intra-assay coefficient of variation was $2 \cdot 7 \%$.

\section{Determination of prostate specific acid phosphatase (PSAP) levels}

PSAP levels were measured in the culture medium by the method of Tenniswood et al. (1976). Para-nitrophenyl phosphate (4\%) was buffered to $\mathrm{pH} 4.85$ using an equal volume of $0 \cdot 1 \mathrm{M}$ citrate buffer, $\mathrm{pH} 4 \cdot 85$. To $1 \mathrm{ml}$ acid-buffered substrate, $0.2 \mathrm{ml} 0.2 \mathrm{M}$ DL-tartarate was added to give a final assay concentration of $0.015 \mathrm{M}$ L-tartarate. Culture medium $(0 \cdot 2 \mathrm{ml})$ was added and the reaction was initiated by incubation at $37^{\circ} \mathrm{C}$ for $30 \mathrm{~min}$. The reaction was terminated by adding $3.8 \mathrm{ml} 0.1 \mathrm{M}$ sodium hydroxide. Absorbance was measured at $415 \mathrm{~nm}$ in a Shimadzu spectrophotometer.

\section{Statistical analysis}

Changes in different parameters were compared using one-way analysis of variance; $P<0 \cdot 05$ was considered as significant. 

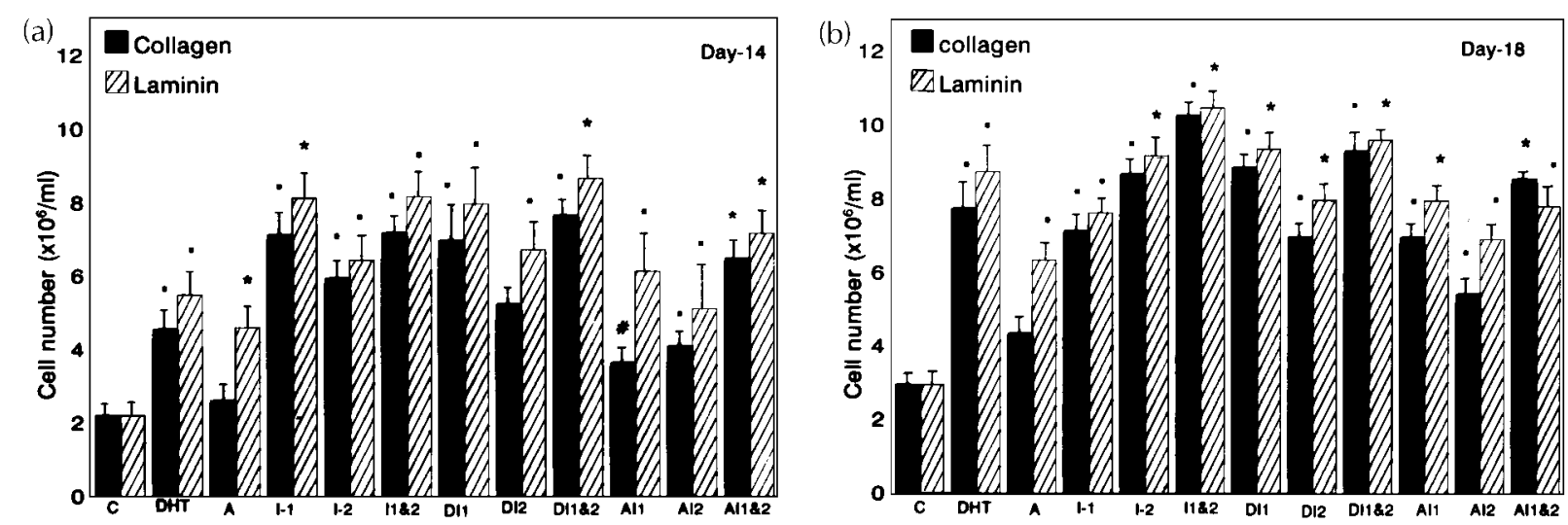

Figure 1 The number of rhesus monkey prostate epithelial cells attached to collagen IV- or laminin-coated flasks on (a) day 14 and (b) day 18 of culture. $C=$ control cells incubated without steroids; DHT=20 nM DHT; $A=20 \mathrm{nM}$ androstenedione; I-1 = IGF-I; I-2=IGF-II; I1\&II=combination of IGF-I and IGF-II; DI1=DHT+IGF-I; DI2=DHT+IGF-II; DI1\&2=DHT+IGF-I and IGF-II; $\mathrm{Al} 1=$ androstenedione $+\mathrm{IGF}-\mathrm{I} ; \mathrm{AI} 2=$ androstenedione $+\mathrm{IGF}-\mathrm{II} ; \mathrm{AI} 1 \& 2=$ androstenedione $+\mathrm{IGF}-\mathrm{I}$ and IGF-II. Growth factors were used at a concentration of $10 \mathrm{ng} / \mathrm{ml}$. ${ }^{*} P<0 \cdot 001, \boldsymbol{\square} P<0 \cdot 01, \# P<0 \cdot 05$ compared with corresponding controls.

\section{Results}

Influence of SCM on epithelial cells in culture in collagen $I V$ and laminin-coated flasks

When prostate epithelial cells were cultured in collagen IV- or laminin-coated flasks without steroids and growth factors, the number of cells which attached were similar in the presence or absence of SCM on all days of culture. SCM also did not influence cell proliferation in the presence of DHT or androstenedione on all days of culture. When DHT was added to cells, an increase in the number of cells $(P<0 \cdot 01)$ attached was seen on day 14 irrespective of the presence or absence of SCM, compared with controls. On subsequent days of culture, cell proliferation increased to a maximum on day 18 , compared with days 14 and 16. Laminin was more effective than collagen IV in supporting cell proliferation and attachment in the presence of DHT. A larger number of cells was seen attached to laminin-coated than collagen IV-coated flasks (Fig. 1).

A comparison of the effects of DHT and androstenedione showed that the number of cells attached was greater in the presence of DHT than of androstenedione throughout the study in collagen IV- and laminin-coated flasks (Fig. 1)

\section{Effects of IGFs on cell number}

IGF-I, IGF-II or a combination of IGF-I and -II significantly increased the number of cells that attached from days 14 to 18 , in the presence or absence of SCM, compared with corresponding controls, in both collagen IV- and laminin-coated flasks (Fig. 1). Maximum proliferation was in the presence of a combination of IGF-I and -II which was nearly $3 \cdot 5$-fold higher than the controls. The number of cells attached were more or less similar $(P>0 \cdot 05)$ in collagen IV- or laminin-coated flasks.

\section{Effects of combination of IGFs and steroids on cell number}

The addition of DHT or androstenedione along with growth factors increased significantly $(P<0.05)$ the number of cells attached to collagen IV- or laminin-coated flasks, in the presence or absence of SCM, on all days of culture, compared with controls (Fig. 1); androstenedione was less effective than DHT. Significant differences were not seen in the number of cells attached in the presence of IGF-I+IGF-II along with DHT; the number of cells attached was significantly lower $(P<0 \cdot 05)$ in the presence of androstenedione compared with DHT. SCM increased cell proliferation in the presence of androstenedione and IGFs in collagen IV- or laminin-coated flasks to variable degrees on different days of culture.

\section{Effects of steroids and growth factors on thymidine incorporation}

The addition of DHT or androstenedione increased (1.4to $1 \cdot 7$-fold $)(P<0 \cdot 05)$ the percentage incorporation of thymidine on days 16-18 of culture irrespective of the presence or absence of SCM in both collagen IV- and laminin-coated flasks compared with controls. The percentage incorporation on day 18 of culture is shown in Fig. 2 while that on day 16 is not shown. By day 18, the percentage incorporation of thymidine was not significantly different $(P>0 \cdot 05)$ in the presence of DHT or androstenedione, in collagen IV- and laminin-coated flasks.

IGFs increased thymidine incorporation into cells by day 16 of culture in collagen IV-and laminin-coated flasks 


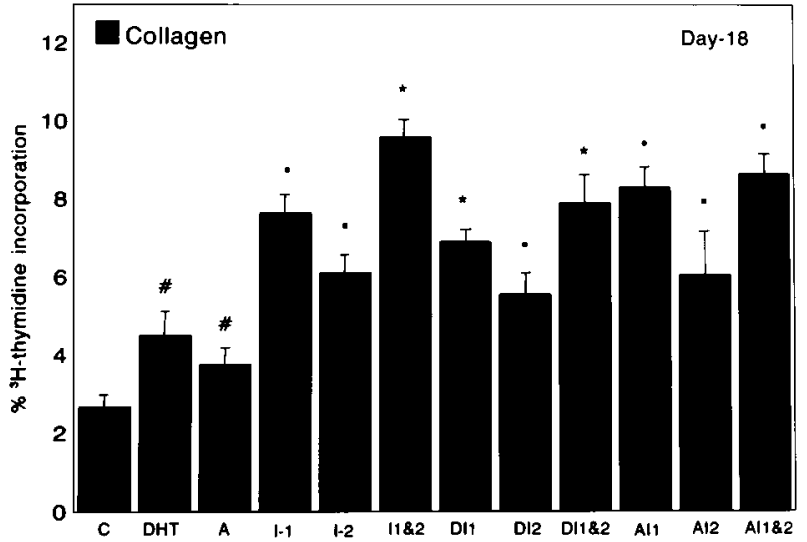

Figure 2 The percentage incorporation of $\left[{ }^{3} \mathrm{H}\right]$ thymidine to the rhesus monkey prostate epithelial cells attached to collagen IV-coated flasks on day 18. $\mathrm{C}=$ control cells incubated without steroids; DHT=20 nM DHT; A=20 nM androstenedione; I-1=IGF-I; I-2=IGF-II; I1\&II=combination of IGF-I and IGF-II; DI1=DHT+IGF-I; DI2=DHT+IGF-II; DI1\&2=DHT+IGF-I and IGF-II;

Al1=androstenedione +IGF-I; Al2=androstenedione+IGF-II; Al1\&2=androstenedione+IGF-I and IGF-II. Growth factors were used at a concentration of $10 \mathrm{ng} / \mathrm{ml} .{ }^{*} P<0 \cdot 001, \mathbb{D} P<0 \cdot 01$, $\# P<0.05$ compared with corresponding controls.

(not shown) compared with controls, and remained at this level on day 18 except in collagen IV-coated flasks containing IGF-I and -II in which a significant $(P<0 \cdot 05)$ increase in incorporation was seen on day 18 (Fig. 2). The percentage incorporation of $\left[{ }^{3} \mathrm{H}\right]$ thymidine was greater in collagen IV-coated than in laminin-coated flasks (not shown). The incorporation of $\left[{ }^{3} \mathrm{H}\right]$ thymidine in the presence of steroids and growth factors was not influenced by the addition of SCM except on day 18 when androstenedione and IGF-II were added. Maximum incorporation was in the presence of IGF-I and -II in collagen IV-coated flasks on day 18 which was nearly $3 \cdot 6$-fold higher than in controls.

\section{Changes in the PSA levels}

In collagen IV-coated flasks, DHT alone or in combination with IGF-I, IGF-II or IGF-I+IGF-II increased PSA secretion to the maximum in the presence of SCM by day 18 (Table 1). In the presence of SCM, androstenedione increased PSA on day 18 compared with day 16, whereas DHT was less effective. Maximum stimulatory effect on PSA secretion was seen when DHT or androstenedione were combined with both IGFs (Table 1).

In laminin-coated flasks, more or less similar results were obtained (Table 1). Maximum secretion of PSA was seen when both IGFs were added along with SCM. Addition of DHT or androstenedione to the combination of growth factors did not increase PSA secretion over that seen with growth factors alone, but inhibited secretion of
Table 1 Levels of PSA $(\mathrm{ng} / \mathrm{ml})$ in the medium on days 16 and 18 of culture of rhesus monkey prostate epithelial cells in collagen IVand laminin-coated flasks in the presence of SCM

\begin{tabular}{|c|c|c|c|c|}
\hline & \multicolumn{2}{|c|}{ Collagen } & \multicolumn{2}{|l|}{ Laminin } \\
\hline & Day 16 & Day 18 & Day 16 & Day 18 \\
\hline \multicolumn{5}{|l|}{ Treatment } \\
\hline Control & $1 \cdot 37$ & $5 \cdot 68$ & $2 \cdot 85$ & $2 \cdot 95$ \\
\hline DHT & $3 \cdot 07$ & $8 \cdot 37$ & $4 \cdot 91$ & $8 \cdot 37$ \\
\hline DHT+IGF-I & $9 \cdot 00$ & $17 \cdot 11$ & $6 \cdot 12$ & $7 \cdot 44$ \\
\hline DHT+IGF-II & $7 \cdot 03$ & $8 \cdot 52$ & $3 \cdot 34$ & $4 \cdot 49$ \\
\hline DHT+IGF-I \& -II & $9 \cdot 19$ & $17 \cdot 57$ & $6 \cdot 66$ & $17 \cdot 39$ \\
\hline A & $5 \cdot 85$ & $9 \cdot 37$ & $3 \cdot 60$ & $6 \cdot 59$ \\
\hline$A+I G F-I$ & $6 \cdot 52$ & $19 \cdot 40$ & $2 \cdot 57$ & $12 \cdot 56$ \\
\hline$A+I G F-I I$ & $2 \cdot 52$ & $8 \cdot 13$ & $4 \cdot 29$ & $5 \cdot 19$ \\
\hline$A+I G F-I \&-I I$ & $12 \cdot 80$ & $28 \cdot 59$ & $10 \cdot 83$ & $20 \cdot 81$ \\
\hline IGF-I & $12 \cdot 74$ & $19 \cdot 68$ & 11.69 & $21 \cdot 03$ \\
\hline IGF-II & $3 \cdot 07$ & $7 \cdot 63$ & $5 \cdot 47$ & $9 \cdot 43$ \\
\hline IGF-I \& -II & $15 \cdot 37$ & $32 \cdot 98$ & $14 \cdot 36$ & $27 \cdot 06$ \\
\hline
\end{tabular}

$\mathrm{A}=$ androstenedione. Androstenedione and DHT were added at a concentration of $20 \mathrm{nM}$ and IGF-II at a concentration of $10 \mathrm{ng} / \mathrm{ml}$.

PSA markedly. Of the two IGFs, IGF-I was more potent in inducing secretion of PSA than IGF-II irrespective of the ECM substrate used.

\section{Changes in PSAP levels}

The secretion of PSAP was significantly elevated both by DHT and androstenedione from day 14 to day 18, compared with controls in collagen IV-coated (Fig. 3a) and laminin-coated (not shown) flasks. This effect was very marked in the presence of SCM particularly in collagen IV-coated flasks. IGF-I, or a combination of IGF-I and IGF-II increased PSAP secretion nearly twofold when SCM was added, in both collagen IV- and laminincoated flasks (not shown); IGF-II alone was less effective (Fig. 3a).

The addition of DHT, SCM and growth factors increased PSAP secretion to a greater degree than caused by the respective IGFs or DHT alone; of these, IGF-II increased PSAP secretion to a lesser degree (Fig. 3b). Control flasks showed enhanced PSAP secretion in the presence of SCM.

\section{Histology}

The prostate epithelial cells in culture stained intensely with monoclonal antibodies for epithelial cell cytokeratin, indicating that the cells cultured were of epithelial origin (Fig. 4).

On day 7 of culture in collagen IV-coated flasks, colony formation was seen and the cells showed differentiation, with the cytoplasm containing vacuoles and secretory materials even in the absence of steroids or growth factors. By day 10 of culture, subconfluence was established and 

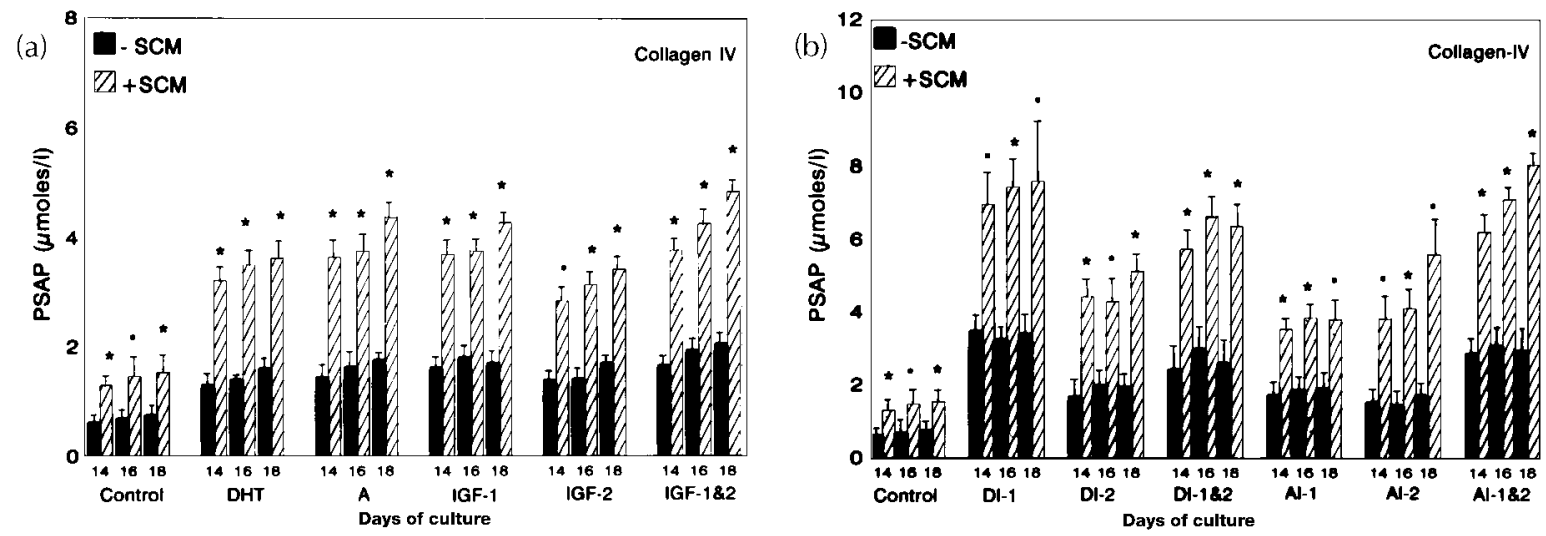

Figure 3 Changes in PSAP levels in collagen IV-coated flasks on days 14,16 and 18 in the presence and absence of SCM. (a) Control=control cells incubated without steroids; DHT=20 nM DHT; A $=20 \mathrm{nM}$ androstenedione; IGF-1 =IGF-I; IGF-2=IGF-II; IGF-1\&2= combination of IGF-I and IGF-II. (b) Control=control cells incubated without steroids; DI-1 =DHT + IGF-I; DI-2 = DHT + IGF-II; DI-1\&2 =DHT + IGF-I and IGF-II; Al-1 = androstenedione + IGF-I; Al-2=androstenedione + IGF-II; Al-1\&2 = androstenedione+IGF-I and IGF-II. Growth factors were used at a concentration of $10 \mathrm{ng} / \mathrm{ml} .{ }^{*} P<0 \cdot 001, \mathbf{\square} P<0 \cdot 01$ compared with corresponding controls.

by day 12 the cells become confluent. SCM in combination with androstenedione or DHT resulted in marked increase in secretory activity of the cells on day 18 . In studies using IGFs, maximum secretory activity was seen in flasks containing both IGFs and SCM; the cell cytoplasm contained large numbers of vacuoles and secretory materials (Fig. 5) whereas in the absence of SCM the effect was less pronounced. The addition of DHT or androstenedione and IGF-I induced pronounced increase in secretory activity of the cells in the presence of SCM. Similar results were obtained in laminin-coated flasks.

\section{Discussion}

In this study proliferation of prostate epithelial cells and secretion of marker proteins specific to prostate (PSA and PSAP) were observed when rhesus monkey prostate

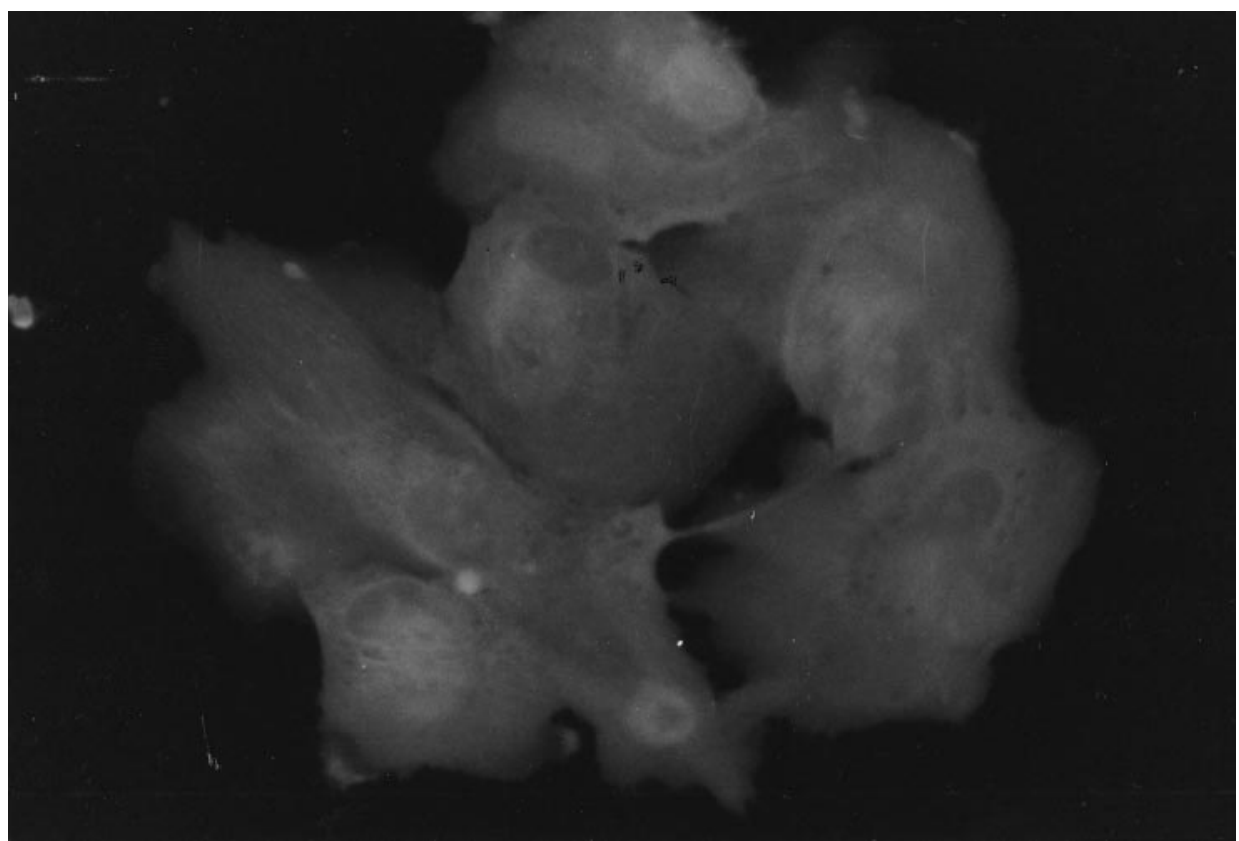

Figure 4 Epithelial cells in culture stained intensely with monoclonal antibody for epithelial cell cytokeratin. Magnification $\times 715$. 


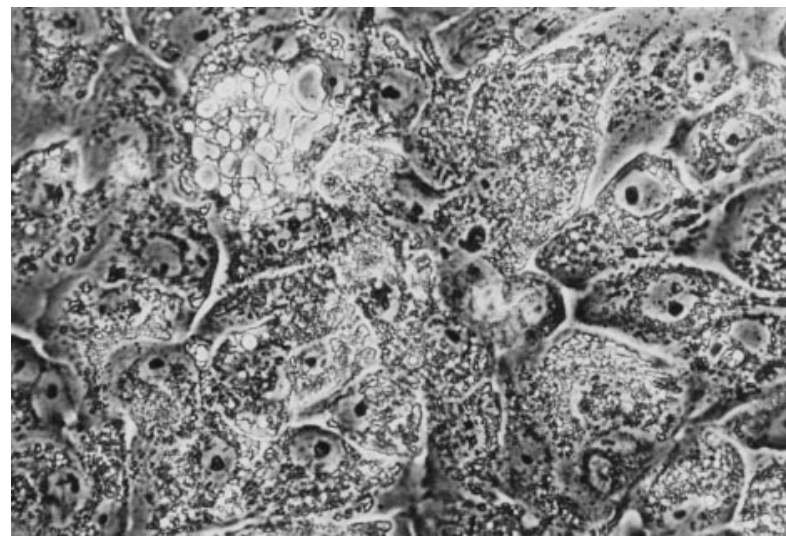

Figure 5 Primary culture of prostate epithelial cells on day 18 of culture in collagen IV-coated flasks in the presence of IGF-I and -II and SCM. The cell cytoplasm showed large amounts of secretory material and vacuoles. Magnification $\times 450$.

epithelial cells were cultured in vitro for 18 days using extracellular matrix components like collagen IV or laminin as substratum. The addition of steroids (DHT or androstenedione), IGFs or a combination of steroids and growth factors increased cell number and thymidine incorporation even in the absence of SCM. However, the addition of SCM had a marked effect in enhancing the secretory activity of the cells, particularly the secretion of PSAP. The use of ECM components like collagen IV or laminin was able to support cell proliferation in the presence of hormones and growth factors. The ECM, composed of stromal elements, is synthesized by mesenchymal and epithelial cells through a process which requires dynamic cell-cell interaction (Martin et al. 1984). The major components of ECM are collagen, elastin, proteoglycans, glycoprotein fibrils and anchorage proteins such as fibronectin and laminin and its composition varies in different tissues (Kleinman et al. 1981). Murray et al. (1979) also reported a four- to fivefold increase in the attachment of epidermal cells in collagen IV-coated flasks than in flasks coated with types I-III collagen. Collagen substrate enhances the attachment, growth and differentiation of various cell types (Ehrman \& Gey 1956, Klebe 1974) and cells attach to collagen or laminin substrates not directly but through membrane proteins like fibronectin (Rouslahti et al. 1973). These clearly indicate that stromal-epithelial cell interactions play an important role in androgen-induced regulation of prostate epithelial cell growth and differentiation (Kozlowski et al. 1991, Tenniswood 1986).

In this study, laminin was more effective than collagen IV in increasing the number of cells attached to the flasks. Laminin is an attachment glycoprotein present in the basement membrane which mediates the attachment of epithelial cells to type IV collagen (Martin et al. 1984). This study, therefore, conclusively demonstrated the important role of ECM proteins in the attachment and differentiation of prostate epithelial cells. Reid \& Jefferson (1984) have suggested that ECM exerts its influence by stabilizing hormones and growth factors which interact with receptors on the cell membrane or with the cytoskeleton.

The results also indicated that steroidal hormones like DHT and androstenedione exert positive influences on cell proliferation and secretion even in the absence of stromal cell medium when cells are grown on collagen IVor laminin-coated substratum. Among the steroids used, DHT was more effective in increasing cell number whereas cell secretion could be induced to a more or less similar degree by DHT or androstenedione. It is known that DHT is the principal intracellular androgen which influences the development and differentiation of the prostate epithelial cells in vivo (Bruchovsky \& Wilson 1968, Isaacs et al. 1983, Wilson 1987). Prostate epithelial cells possess $5 \alpha$-reductase which converts peripheral testosterone to DHT (Wilson 1980). In organ culture, DHT was more effective in maintaining the height and secretory activity of the prostate cells, whereas androgen metabolites like androstanediol and androstenedione were less effective (Baulieu et al. 1968). Similar results have been reported in the androgen-sensitive prostate cancer cell line LNcaP (Sonnenschein et al. 1989, Belanger et al. 1990, Lee et al. 1995). In this study, the difference in cell number in control and treated was much less than would be indicated by the increase in thymidine incorporation. This indicates the likelihood of significant amounts of cell death. Alternatively, tritiated thymidine incorporation may not reflect S-phase content but also unscheduled DNA repair.

Among the growth factors, IGF-I was more effective than IGF-II in inducing cell proliferation and cell secretion; a combination of the two IGFs induced better stimulation. But optimal stimulation could be obtained by adding a steroid with a combination of the two growth factors. IGFs are mitogenic peptides which act as endocrine, paracrine and autocrine modulators of normal and malignant cells (Daughaday \& Rotwein 1989) and, along with androgens, influence the hyperplastic development of the human prostate (Fiorelli et al. 1991). The results of the present study are in agreement with those of Cohen et al. (1991), who have reported that IGFs are mitogenic in the primary culture of human prostate epithelial cells.

Earlier reports indicate that prostate epithelial cells of rat or human grown on plastic tissue culture base proliferate in the absence of DHT or testosterone but do not undergo differentiation or secrete marker proteins (Mckeehan et al. 1984, Chaproniere \& Mckeehan 1986, Sherwood et al. 1989). The results of the present study also showed that the prostate epithelial cells grown in culture in the absence of DHT and androstenedione or growth factors (control) undergo colony formation and confluence to a limited degree but show very little differentiation and secretion. 
In conclusion, we have been able to establish an in vitro primary culture of prostate epithelial cells from the rhesus monkey using extracellular matrix proteins, steroids and growth factors as additional supplements. The cells were viable for 18 days and secreted marker proteins like PSA and PSAP. This culture system could be useful to study prostate cell physiology and to identify drugs that can inhibit cell proliferation. The rhesus monkey was chosen as the animal model in view of its close phylogenetic similarity to the human.

\section{Acknowledgements}

Financial support from the All India Institute of Medical Sciences to T S U is gratefully acknowledged. The project was funded by the Council of Scientific and Industrial Research, Government of India, New Delhi.

\section{References}

Baulieu EE, Lasnitzki I \& Robel P 1968 Metabolism of testosterone and action of metabolites on prostate glands grown in organ culture. Nature 219 1155-1156.

Belanger C, Veilleux R \& Labrie R 1990 Stimulatory effect of androgens, estrogens, progestins and dexamethasone on the growth of the LNcaP human prostate cancer cells. Annals of the New York Academy of Sciences 595 399-402.

Bruchovsky N \& Wilson JD 1968 The conversion of testosterone to $5 \alpha$-androstan-17 $\beta$-ol 3 -one by rat prostate in vivo and in vitro. Journal of Biological Chemistry 243 2012-2121.

Chaproniere DM \& Mckeehan WL 1986 Serial culture of single adult human prostatic epithelial cells in serum-free medium containing low calcium and a new growth factor from bovine brain. Cancer Research 46 819-824.

Chiarodo A 1991 National Cancer Institute round table on prostate cancer: future research direction. Cancer Research 51 2498-2505.

Cohen A, Pheel DM, Lamson G \& Rosenfeld RG 1991 Insulin like growth factors (IGFs), IGF receptors, and IGF-binding proteins in primary culture of prostatic cells. Journal of Clinical Endocrinology and Metabolism 73 401-407.

Cunha GR, Donjacour AA, Cooke PS, Mee S, Bigsby RM, Higgins SJ \& Sugimura Y 1987 The endocrinology and developmental biology of the prostate. Endocrine Reviews 8 338-447.

Daughaday WH 1990 The possible autocrine/paracrine and endocrine roles of insulin-like growth factors of human tumors. Endocrinology $1271-4$.

Daughaday W \& Rotwein P 1989 Insulin-like growth factors I and II. Peptides, messenger ribonucleic acid and gene structure, serum and tissue concentrations. Endocrine Reviews 10 68-91.

Ehrman RL \& Gey GC 1956 The growth of cells on a transparent gel of reconstituted rat tail collagen. Journal of National Cancer Institute 16 1375-1390.

Fiorelli G, Bellis A \& Longo A 1991 Insulin-like growth factor-I receptor in human hyperplastic prostate tissue: characterization, tissue localization and their modulation by chronic treatment with gonadotropin releasing hormone analog. Journal of Clinical Endocrinology and Metabolism 72 740-746.

Isaacs JT, Brendler CB \& Walsh PC 1983 Changes in the metabolism of dihydrotestosterone in the hyperplastic human prostate. Journal of Clinical Endocrinology and Metabolism 56 139-146.
Klebe RJ 1974 Isolation of collagen-dependent cell attachment factor. Nature 250 248-251.

Kleinman HK, Klebe RJ \& Martin GR 1981 Role of collagenous matrices in the adhesion and growth of cells. Journal of Cell Biology 88 473-485.

Kozlowski JM, Sherwood ER, Fong CJ \& Lee C 1991 The impact of androgen, extracellular matrix, and stroma upon proliferation and differentiation of benign and malignant prostatic epithelial cells. In Molecular and Cellular Biology of Prostate Cancer, pp 27-50. Eds JP Karr, DS Coffey, RS Smith \& DJ Tindall. New York: Plenum Press.

Lee C, Debra MS, Julia AS, David Z, Isaac K, Irma A, Norman S, Gail SP \& James MK 1995 Regulation of proliferation and production of prostate-specific antigen in androgen sensitive prostate cancer cell LNcaP, by dihydrotestosterone. Endocrinology 136 796-803.

MacDonald A, Chisholm GD \& Habib FK 1990 Production and response of a human prostatic cancer line to transforming growth factors. British Journal of Cancer 62 579-584.

Mckeehan WL, Adams PS \& Rosser MP 1984 Direct mitogenic effects of insulin, epidermal growth factor, glucocorticoid, cholera toxin, unknown pituitary factors and possibly prolactin but not androgen on normal rat prostate epithelial cells in serum free primary cell culture. Cancer Research 44 1998-2010.

Martin GR, Kleinman HK, Terranova VP, Ledbetter S \& Hassel JR 1984 The regulation of basement membrane formation and cell matrix interaction by defined supramolecular complexes. In Basement Membrane and Movements, pp 197-212. Ed PM Bernfied. London: Pitman.

Murray JC, Stingal G, Kleinman HK, Martic GR \& Katz SI 1979 Epidermal cell adhere preferentially to type IV collagen. Journal of Cell Biology 80 197-201.

Reid LM \& Jefferson DM 1984 Cell culture studies using extracts of extracellular matrix to study growth and differentiation in mammalian cells. In Mammalian Cell Culture, pp 239-280. Ed JP Mather. New York: Plenum Press.

Rouslahti E, Vahini A, Kunsela P \& Linder E 1973 Fibroblast surface antigen: a new serum protein. Biochimica et Biophysica Acta $\mathbf{3 2 2}$ 353-358.

Sherwood ER, Berg LA, McEwan RM, Pasciak RM, Kozlowski JM \& Lee C 1989 Two dimensional protein profiles of cultured stromal and epithelial cells from hyperplastic human prostate. Journal of Cell Biochemistry 40 211-214.

Sivashanmugam P \& Rajalakshmi M 1997 Sperm maturation in rhesus monkey. Changes in ultrastructure, chromatin condensation, and lipid bilayer. Anatomical Record 247 25-32.

Sonnenschein C, Olea N, Pasanen ME \& Soto AM 1989 Negative controls of cell proliferation: human prostate cancers and androgens. Cancer Research 49 3474-3481.

Tenniswood M 1986 Role of epithelial and stromal interactions in the control of gene expression in the prostate: an hypothesis. The Prostate 9 375-385.

Tenniswood M, Bird CE \& Clark AF 1976 Acid phosphatases: Androgen dependent markers of rat prostate. Canadian Journal of Biochemistry 54 350-357.

Wilson JD 1980 The pathogenesis of benign prostatic hyperplasia. American Journal of Medicine 68 745-756.

Wilson JD 1987 The testis and prostate. New England Journal of Medicine 317 628-629.

Received 3 November 1998

Revised manuscript received 2 February 1999

Accepted 5 May 1999 